\title{
Znaczenie oceny minimalnej choroby resztkowej u chorych na przewlekłą białaczkę limfocytową
}

\section{Significance of minimal residual disease assessment in patients with chronic lymphocytic leukemia}

\author{
Bartosz Puła ${ }^{1}$, Adrian Burdacki², Marek Dudziński ${ }^{2}$ \\ ${ }^{1}$ Klinika Hematologii, Instytut Hematologii i Transfuzjologii, Warszawa \\ ${ }^{2}$ Klinika Hematologii, Kliniczny Szpital Wojewódzki nr 1 im. F. Chopina, Rzeszów
}

\begin{abstract}
Streszczenie
Przewlekta biataczka limfocytowa (CLL) jest choroba limfoproliferacyjna o zróżnicowanym przebiegu klinicznym wywodzaca sie z dojrzatych limfocytów B. W okoto $60 \%$ przypadków ze wzgledu na zaawansowanie choroby konieczne jest rozpoczecie leczenia. Zastosowanie intensywnej immunochemioterapii pozwala uzyskać dtugotrwate remisje u części pacjentów, niemniej mimo uzyskania catkowitych odpowiedzi dochodzi do wznowy choroby. Jej nawrót ttumaczy się obecnościa rezydualnych komórek biataczkowych w szpiku kostnym, krwi obwodowej czy wezłach chtonnych, określanych mianem minimalnej choroby resztkowej (MRD). Zastosowanie cytometrii przeptywowej (FLC) oraz metod molekularnych umożliwia wykrycie pozostatych komórek biataczkowych z czutościa siegajaca co najmniej 10-5, co pozwala na doktadniejsze określenie odpowiedzi na leczenie. Eliminacja choroby resztkowej stanowi istotny czynnik rokowniczy dtugotrwatej odpowiedzi na immunochemioterapię. Ponadto znaczenie oceny MRD zwiększa się $w$ zwiazku $z$ możliwościa indywidualizacji leczenia CLL oraz oceny jego skuteczności bez konieczności dtugoletniej obserwacji chorych. W niniejszej pracy podsumowano znaczenie kliniczne oceny MRD w CLL ze szczególnym uwzglednieniem metodyki opartej na FLC.
\end{abstract}

Słowa kluczowe: przewlekła białaczka limfocytowa, diagnostyka, minimalna choroba resztkowa, immunochemioterapia, cytometria przepływowa

Hematologia 2018; 9, 2: 123-132

\begin{abstract}
Chronic lymphocytic leukemia (CLL) is a lymphoproliferative disorder of mature B lymphocytes characterized by a heterogenous clinical course. Approximately $60 \%$ of cases require treatment initiation due to disease advancement. Immunochemotherapy enables achievement of durable remissions in some of the patients, however despite the observed complete responses relapses occur. These are explained by the persistence of residual leukemic cells in blood, bone marrow and lymph nodes, defined as minimal residual disease (MRD). Use of flow cytometry (FLC) and molecular methods in assessment of treatment response allows for more detailed response quantification and detection of leukemic cells with at least $10^{-5}$ sensitivity. Elimination of $M R D$ is an important prognosticator of durable remissions following immunochemotherapy. Furthermore, the significance of MRD
\end{abstract}

Adres do korespondencji: Bartosz Puła, Klinika Hematologii, Instytut Hematologii i Transfuzjologii, ul. Indiry Gandhi 14, 02-776 Warszawa, tel. +48 223496 316, faks +48 223496 334, e-mail: bartosz.pula@gmail.com 
assessment increases due to its possible role in CLL treatment individualization and as a potential surrogate marker of response without the need of long lasting observations. Herein in this publication, the clinical significance of MRD assessment emphasizing FLC methodology is summarized.

\section{Key words: chronic lymphocytic leukemia, diagnostics, minimal residual disease, immunochemotherapy, flow cytometry}

Hematologia 2018; 9, 2: 123-132

\section{Wprowadzenie}

Przewlekła białaczka limfocytowa (CLL, chronic lymphocytic leukemia) jest nowotworem charakteryzującym się klonalną proliferacją dojrzałych limfocytów B i ich akumulacją we krwi obwodowej, szpiku, narządach limfatycznych oraz rzadziej pozalimfatycznych [1,2]. Komórki białaczkowe odpowiadają subpopulacji immunoniekompetentnych limfocytów B i cechują się charakterystycznym wzorem ekspresji antygenów powierzchniowych ze współwystępowaniem markerów linii B (CD19, CD20 i CD23) i antygenu CD5 oraz niską ekspresją immunoglobulin powierzchniowych (sIg, surface immunoglobulin) [3]. Przebieg choroby początkowo jest indolentny i rozpoznaje się ją przypadkowo bez towarzyszących objawów klinicznych; $2 / 3$ pacjentów nie wymaga leczenia przy rozpoznaniu, a u połowy $z$ nich choroba nie ulegnie progresji i nie będą wymagali terapii do końca życia. Pozostała $1 / 3$ chorych $z$ powodu zaawansowania choroby będzie wymagała leczenia, począwszy od momentu postawienia diagnozy [4]. Tak zróżnicowany przebieg kliniczny jest uwarunkowany dużą heterogennością nagromadzonych zmian genetycznych oraz epigenetycznych występujących w CLL [5-8].

W zdecydowanej większości przypadków CLL pozostaje chorobą nieuleczalną ze względu na zachorowania w grupie osób starszych, u których nie można zastosować intensywnej immunochemioterapii lub przeszczepienia allogenicznych krwiotwórczych komórek macierzystych (allo-HSCT, allogeneic hematopoetic stem cell transplantation). Osoby w niskim stadium zaawansowania choroby oraz ze stabilną chorobą bezobjawową wymagają jedynie obserwacji (strategia watch \& wait) $[9,10]$. W przypadkach wymagających leczenia standardem jest immunochemioterapia oparta na przeciwciele anty-CD20 w połączeniu $z$ fludarabiną oraz cyklofosfamidem (FCR, fludarabina, cyklofosfamid, rytuksymab) u młodszych chorych lub chlorambucylem (R-Clb, rytuksymab, chlorambucyl) u starszych pacjentów obciążonych występowaniem innych chorób uniemożliwiających zastosowanie analogów puryn $[11,12]$. Ostatnie lata przyniosły znaczący postęp w leczeniu CLL za sprawą wprowadzenia nowych przeciwciał anty-CD20, tj. ofatumumabu [13] oraz obinutuzumabu $[14,15]$ czy drobnocząsteczkowych inhibitorów receptora B-komórkowego (BCRi, B-cell receptor inhibitors), tj. ibrutynibu [16, 17] i idelalizybu [18], jak również inhibitora antyapoptotycznego białka BCL2 (B-cell lymphoma 2) — wenetoklaksu [19]. Pozwalają one kontrolować chorobę również w najgorzej rokujących przypadkach $\mathrm{z}$ obecnością delecji 17 p lub mutacji TP53 [8, 20, 21].

Zastosowanie powyższych schematów immunochemioterapii u części chorych pozwala uzyskać długotrwałe remisje, szczególnie u młodych chorych $z$ obecnością mutacji w części zmiennej łańcucha ciężkiego immunoglobulin (IgHV, immunoglobulin heavy chain variable) oraz bez niekorzystnych cytogenetycznych czynników ryzyka [11,22]. Zaobserwowano jednak, że uzyskanie całkowitej remisji (CR, complete remission) jest parametrem niedostatecznie korelującym $z$ czasem przeżycia wolnego od progresji (PFS, progression-free survival) czy całkowitego przeżycia (OS, overall survival) [23]. U części pacjentów, u których wykazano CR w odpowiedzi na immunochemioterapię, stwierdza się obecność rezydualnych komórek białaczkowych niewykrywalnych standardowymi metodami obrazowymi czy laboratoryjnymi. Zastosowanie czulszych metod, tj. cytometrii przeplywowej (FLC, flow cytometry) lub metod molekularnych, pozwala na ich detekcję w krwi obwodowej i szpiku kostnym $z$ czułością 1 na 10 tys. -100 tys. komórek $\left(10^{-4}-10^{-5}\right)$ [24-26]. Obecność tych rezydualnych komórek białaczkowych określa się mianem minimalnej choroby resztkowej (MRD, minimal residual disease). Jako stan eradykacji MRD, zgodnie z zaleceniami iwCLL (International Workshop on Chronic Lymhocytic Leuekmia) oraz Europejskiej Agencji Leków (EMA, European Medicines Agency), przyjmuje się obecność mniej niż 1 komórki CLL na 10 tys. leukocytów $\left(10^{-4}\right)$, nawet jeżeli stosowana metoda pozwala na bardziej precyzyjną ocenę MRD [27]. Uzyskanie eradykacji MRD na poziomie $10^{-4}$ po immunochemioterapii pozwala uzyskać długotrwałe PFS oraz OS i znacznie lepiej koreluje 
Tabela 1. Zestawienie przeciwciał najczęściej stosowanych w oznaczaniu minimalnej choroby resztkowej

Table 1. List of antibodies most often utilized for minimal residual disease assessment

\begin{tabular}{|l|c|c|}
\hline Metoda & Probówki/markery & $\begin{array}{c}\text { Minimalna liczba leukocytów } \\
\text { dla czułości 10 }\end{array}$ \\
\hline 4-kolorowa (5 probówek) & Kappa/lambda/CD19/CD5 \\
& CD45/CD14/CD19/CD3 & $4-20$ \\
& CD20/CD38/CD19/CD5 \\
& CD81/CD22/CD19/CD5 & \\
\hline 6-kolorowa (2 probówki) & CD43/CD79b/CD19/CD5 & \\
\hline 8-kolorowa (1 probówka) & CD22/CD38/CD5/CD19/CD79b/CD20 & $2-10$ \\
\hline
\end{tabular}

z tymi parametrami niż klasycznie zdefiniowana remisja według iwCLL $[22,23,28]$.

Zważywszy na rosnące znaczenie oceny MRD w ocenie skuteczności leczenia CLL w niniejszym opracowaniu omówiono metodykę jej oceny oraz znaczenie w określeniu odpowiedzi na leczenie stosowane u chorych na CLL.

\section{Metodyka oznaczania MRD w CLL}

\section{Cytometria przepływowa}

Cytometria przepływowa jest metodą diagnostyczną dostępną obecnie w każdym ośrodku hematologicznym w Polsce. Większość pracowni dysponuje cytometrami umożliwiającymi jednoczesne oznaczenie 8 fluorochromów (tab. 1). Pierwsze próby standaryzacji oznaczeń MRD w CLL metodą FLC (MRDflow) opierały się na oznaczeniach 4-, a następnie 6-kolorowych [29, 30]. Jakkolwiek obie te techniki pozwalają na osiągniecie rekomendowanego przez iwCLL poziomu czułości $10^{-4}$ [27], to mają jednak istotne ograniczenia wynikające z konieczności podziału pobranej od pacjenta próbki krwi na odpowiednio pięć i dwie probówki, co może prowadzić do zmniejszenia czułości badania oraz wymaga pobrania znacznej objętości krwi w celu zapewnienia uzyskania wymaganej liczby komórek. Przyjmuje się, że aby badanie było wiarygodne i osiągało czułość $10^{-4}$ należy poddać analizie co najmniej milion komórek w każdej probówce. Jednocześnie, aby badanie ilościowe określić jako w pełni wiarygodne, należy zobrazować wyraźną, homogenną populację 50 komórek CLL, co często wymaga analizy znacznie większej liczby leukocytów w probówce niż wspomniany milion [29, 30].

Istotny postęp $\mathrm{w}$ diagnostyce MRD w CLL przyniosło zastosowanie metody 8-kolorowej, która pozwala na jej oznaczenie $z$ zastosowaniem jednej probówki. Podstawami doboru markerów i fluorochromów w przypadku zastosowania tej metody są wcześniejsze protokoły 4- oraz 6-kolorowe [31, 32]. Do badania 8-kolorowego wykorzystuje się mniejszą liczbę przeciwcial, zastosowanie jednej probówki pozwala ocenić większą liczbę komórek, zaś analiza jest prostsza i trwa krócej niż w badaniach 4- i 6-kolorowych. Zastosowanie 8- lub więcej kolorowego, 1-probówkowego protokołu pozwala na osiągnięcie wyższej czułości, sięgającej $10^{-5}-10^{-6}[31,33]$.

Jak dotychczas nie przeprowadzono szerszej standaryzacji oznaczenia MRD w CLL metodą 8-kolorową. W Polsce jest obecnie realizowany projekt służący opracowaniu standardów oceny MRD z zastosowaniem FLC. Nie ustalono dotychczas, czy wyższa czułość badania przekłada się na PFS i OS. Stale trwają prace nad optymalizacja zestawu przeciwciał $\mathrm{w}$ oznaczeniach wielokolorowych, mające na celu podwyższenie czułości i uproszczenie oznaczeń. W ostatnich latach konsorcjum ERIC (European Research Initiative on $C L L)$ opublikowało 6-kolorowy, „szkieletowy” zestaw przeciwciał dla metody 1-probówkowej, uznając dla osiąnięcia czułości $10^{-4}$ za redundantne markery CD22 i CD3 [24]. Eliminacja tych dwóch przeciwciał pozwala w badaniu 8-kolorowym na zastosowanie w ich miejsce nowych markerów, o nieustalonym jeszcze znaczeniu w detekcji MRD (np. ROR1, CD160). Z drugiej strony eliminacja CD22 i CD3 jest możliwa wyłącznie u pacjentów $z$ typowym immunofenotypem CLL i może pogarszać jakość oznaczeń z zakładaną czułością wyższą niż $10^{-4}$ [24].

Do zalet oznaczania MRD metodą cytometryczną należą łatwa dostępność, niski koszt i krótki czas wykonania oznaczenia $z$ analizą oraz brak konieczności posiadania wyjściowej próbki chorego. 
Metoda 8-mio kolorowa pozwala na oznaczenie MRD także w przypadku nietypowych immunofenotypów komórek CLL. Jedyną jak się wydaje wadą tej metody jest duża zależność od aparatury badawczej, zastosowanych klonów przeciwciał oraz operatora. Remedium na powyższe problemy może być przeprowadzenie standaryzacji międzyośrodkowej dotyczącej m.in. ustawień cytometru, preparatyki, zastosowanych klonów przeciwciał, fluorochromów i procedury analizy.

Dla osiągnięcia czułości $10^{-4}$ należy pobrać 1-2 $\mathrm{ml}$ krwi obwodowej lub $1 \mathrm{ml}$ aspiratu szpiku kostnego pacjenta do standardowej probówki z EDTA. Po inkubacji ze znakowanymi przeciwciałami monoklonalnymi do roztworu komórek dodajemy czynnik lizujący erytrocyty a następnie po odwirowaniu zawieszamy w zbuforowanym roztworze soli fizjologicznej i analizujemy w cytometrze przepływowym. Strategia bramkowania obejmuje wyodrębnienie limfocytów B, eliminacje artefaktów prezentujących koekspresję CD19+/ /CD3+ a następnie określenie części wspólnej bramek dla limfocytów B prezentujących charakterystyczną dla CLL ekspresję antygenów CD5, CD43, CD81, CD79b, CD22 oraz CD20. Odsetek limfocytów białaczkowych podajemy w stosunku do ogólu leukocytów odpowiednio krwi lub szpiku. Badanie w cytometrze przepływowym wraz $z$ analizą danych zajmuje 2-3 godzin. Przykładowe badanie MRD wraz ze schematem bramkowania przedstawiono na rycinie 1 .

\section{Metody molekularne}

Badania molekularne pozwalają na jakościową i ilościową ocenę MRD u chorych na CLL. Badanie ASO IgHV PCR (allele-specific oligonucleotide immunoglobulin heavy chain variable gene polymerase chain reaction) jest uważane za referencyjną metodę oznaczania MRD w CLL [34]. Geny kodujące region zmienny lańcucha ciężkiego immunoglobulin $(I g V H)$ limfocytów białaczkowych pacjenta pobranych przed włączeniem leczenia są sekwencjonowane w celu syntezy allelospecyficznych oligoukleotydów dla regionu CDR3 (complementarity-determining region) IgHV, które są następnie wykorzystywane do oznaczania MRD po leczeniu. Badanie ASO IGHV w badaniu ilościowym reakcji łańcuchowej polimerazy (RQ-PCR, real-time quantitative polymerase chain reaction) pozwala osiągnąc czułość na poziomie $10^{-5}[35,36]$. W przypadku zastosowania techniki zagnieżdżonej (nested) metoda pozwala osiagnąć czułość $10^{-6}$, ale bez możliwości oznaczenia ilościowego. Oba warianty badania wymagają zastosowania specyficznych dla pacjenta starterów, a więc uzyskania i sekwencjonowania próbki pacjenta przed leczeniem. Metodyka badania jest pracochłonna, względnie droga i dostępna w niewielu ośrodkach [35, 36].

W ostatnich latach w oznaczaniu MRD w chorobach układu chłonnego dynamicznie rozwija się metoda sekwencjonowania następnej generacji (NGS, next generation sequencing) z zastosowaniem niespecyficznych dla pacjenta starterów [25, 37]. Czułość badania sięga $10^{-6}$, w badaniu jakościowym oraz $10^{-5} \mathrm{w}$ badaniu ilościowym. Metodyka oznaczenia jest mniej czaso- i pracochłonna niż badania $z$ zastosowaniem klasycznego sekwencjonowania. W Polsce metoda NGS pozostaje dostępna jedynie w kilku laboratoriach i według wiedzy autorów nie stosowano jej, jak dotąd, w oznaczaniu MRD $\mathrm{u}$ chorych na CLL. Obie wspomniane metody molekularne można stosować do oznaczania MRD z próbek krwi obwodowej i szpiku kostnego. Porównanie wybranych metod oznaczenia MRD w CLL zestawiono tabeli 2.

\section{Zasadność oceny MRD na podstawie badań klinicznych}

Na potrzeby badań klinicznych poziom uzyskanego stopnia MRD $z$ wykorzystaniem FLC określa sięjako niski $\left(<10^{-4}\right)$, pośredni $\left(\right.$ od $\geq 10^{-4}$ do $\left.<10^{-2}\right)$ oraz wysoki $\left(\geq 10^{-2}\right)$, przy czym uzyskanie niskiego poziomu $\left(<10^{-4}\right)$ określa się mianem negatywizacji MRD według kryteriów iwCLL [38]. W zdecydowanej większości badań do oznaczenia MRD wykorzystywano metody oparte na FLC. W randomizowanym badaniu CLL8, w którym porównywano skuteczność schematu FCR (fludarabina, cyklofosfamid, rytuksymab) ze skutecznością schematu FC (fludarabina, cyklofosfamid) u dotychczas nieleczonych chorych na CLL, wykazano, że schemat FCR pozwala uzyskać wysoki całkowity odsetek odpowiedzi (ORR, overall response rate) wynoszący $90 \%$, z czego $44 \%$ stanowiły CR [11, 22]. Böttcher i wsp. [39] w grupie pacjentów leczonych FCR w porównaniu $z \mathrm{FC}$ wykazali istotnie wyższy odsetek negatywizacji MRD mierzonej we krwi obwodowej $(63 \%$ v. 35\%) oraz szpiku kostnym (44\% v. 28\%). Uzyskanie negatywizacji MRD istotnie korelowało $z$ dłuższymi czasem PFS oraz OS niezależnie od zastosowanego schematu leczenia [39]. Również w badaniu MDACC (MD Anderson Cancer Center) w grupie 237 pacjentów leczonych w pierwszej linii według schematu FCR stwierdzono negatywizację MRD szpiku kostnego u 43\% pacjentów po zakończeniu leczenia, co istotnie korelowało $z$ dłuższymi PFS oraz OS [40]. 


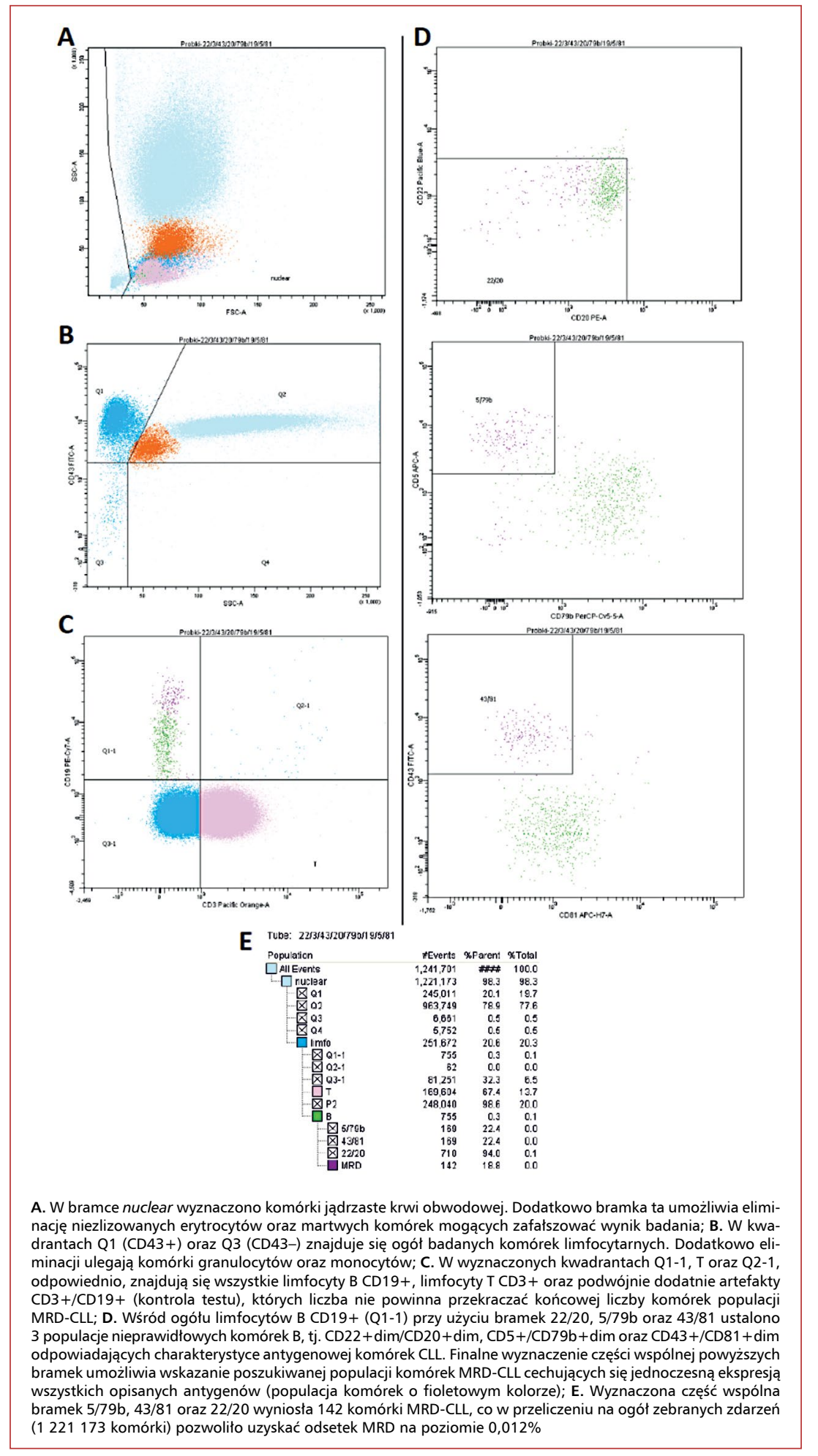

Rycina 1. Przykładowe badanie ilościowe minimalnej choroby resztkowej w przewlekłej białaczce limfocytowej (MRD-CLL) Figure 1. Illustrative quantitative determination of minimal residual disease in chronic lymphocytic leukemia (MRD-CLL)

Negatywizacja MRD jest również możliwa dzięki zastosowaniu mniej intensywnych schematów immunochemioterapii w populacji starszych chorych ze wspólistnieniem innych chorób dyskwalifikujących pacjentów $\mathrm{z}$ intensywnego leczenia. $\mathrm{W}$ ramach randomizowanego trójramiennego 
Tabela 2. Porównanie oznaczania minimalnej choroby resztkowej (MRD) z wykorzystaniem metod cytometrii przepływowej (MRDflow) oraz molekularnych

Table 2. Comparison of examination methods for minimal residual disease (MRD) assessment based on flow cytometry (MRDflow) and molecular methodology

\begin{tabular}{|l|c|c|c|}
\hline Metoda & Czułość & Standaryzacja & Uwagi \\
\hline MRDflow & $\begin{array}{c}10^{-4} \\
\text { (w protokołach 8-10-kolorowych 10-5) }\end{array}$ & Tak & $\begin{array}{c}\text { Nie wymaga próbki przed leczeniem } \\
\text { Powszechnie dostępna } \\
\text { Tania }\end{array}$ \\
\hline ASO IgHV RQ-PCR & $10^{-5}$ & Tak & $\begin{array}{c}\text { Wymaga próbki przed leczeniem } \\
\text { Czasochłonna } \\
\text { Kosztowna } \\
\text { Mało dostępna }\end{array}$ \\
\hline NGS & $10^{-5}$ & Nie & $\begin{array}{c}\text { Kosztowna } \\
\text { Bardzo mało dostępna }\end{array}$ \\
\hline
\end{tabular}

ASO IgHV RQ-PCR (allele-specific oligonucleotide immunoglobulin heavy chain variable gene real-time quantitative polymerase chain reaction) - allelospecyficzna reakcja oligonukleotydowa genu zmiennego łańcucha ciężkiego immunoglobulin z ilościowym badaniem reakcji łańcuchowej polimerazy w czasie rzeczywistym; NGS (next generation sequencing) — sekwencjonowanie następnej generacji

badania CLL11 porównano skuteczność leczenia chlorambucylem w monoterapii oraz według dwóch schematów immunochemioterapii - R-Clb oraz G-Clb (obinutuzumab, chlorambucyl) w grupie 781 dotychczas nieleczonych chorych $[14,15]$. Obinutuzumab to przeciwciało anty-CD20 typu II, które w odniesieniu do rytuksymabu charakteryzuje się wyższym bezpośrednim efektem cytotoksycznym i komórkowym, jednak niższym efektem cytotoksycznym zależnym od aktywacji dopełniacza [41]. Immunochemioterapia G-Clb oraz $\mathrm{R}-\mathrm{Clb}$ w porównaniu $\mathrm{z}$ monoterapią chlorambucylem pozwoliła na uzyskanie wyższego ORR (odpowiednio $78,4 \%, 65,1 \%$ oraz $31,4 \%)$ oraz $\mathrm{CR}(20,7 \%$, $7 \%$ oraz $0 \%)[14,15]$. Odsetek chorych $z$ niskim poziomem MRD mierzonej w szpiku kostnym oraz krwi obwodowej był istotnie wyższy w grupie leczonej G-Clb niż u pacjentów, u których zastosowano schemat R-Clb (szpik kostny 19,5\% v. 2,6\% oraz krew obwodowa $37,7 \%$ v. 3,3\%) [14]. Choć czasy OS w obu grupach były porównywalne, to wyższy odsetek negatywizacji MRD przełożył się na istotnie dłuższe PFS w grupie leczonej zgodnie ze schematem G-Clb (29,2 mies. v. 15,4 mies.) [14]. Ponadto chorzy w grupie, w której podawano obinutuzumab, wymagali leczenia kolejnej linii po 51,1 miesiąca $w$ porównaniu z 38,2 miesiąca w grupie, w której stosowano rytuksymab [15].

Również schemat BR (bendamustyna, rytuksymab) pozwala uzyskać negatywizację MRD. Mediana czasu PFS korelowała dodatnio ze stopniem głębokości uzyskanej odpowiedzi mierzonej we krwi obwodowej (nie uzyskano mediany dla $<10^{-4}$, 32 mies. dla $\geq 10^{-4}$ do $<10^{-2}$ oraz 12 mies. dla $\geq 10^{-2}$ ) [42]. Istotnie dłuższy okres PFS u chorych $z \mathrm{CR} z$ negatywizacją MRD w szpiku kostnym w porównaniu z chorymi z CR bez negatywizacji MRD obserwowano również w grupie chorych leczonych w pierwszej linii według schematu FCM (fludarabina, cyklofosfamid, mitoksantron) [43].

Ocena MRD ma również zastosowanie w przypadku leczenia chorych $z$ nawrotową i oporną CLL $(\mathrm{r} / \mathrm{r}$ CLL, relapse and refractory $C L L)$. Negatywizacja MRD mierzona $z$ zastosowaniem ilościowej reakcji łańcuchowej polimerazy (qPCR, qualitative polymerase chain reaction) przekłada się na dłuższy czas do progresji choroby (TTP, time to progression) w grupie pacjentów $z \mathrm{r} / \mathrm{r}$ CLL leczonych według schematu FCR [44]. Również uzyskanie głębokich odpowiedzi mierzonych $z$ wykorzystaniem FLC wiąże się $z$ dłuższym czasem PFS w przypadkach $\mathrm{r} / \mathrm{r}$ CLL u chorych leczonych alemtuzumabem w monoterapii czy w skojarzeniu $\mathrm{z}$ wysokodawkowanym metyloprednizolonem [45, 46]. Ocena MRD znalazła również zastosowanie w monitorowaniu odpowiedzi u chorych poddanych procedurze allo-HSCT i jest zalecana przez ASBMT (American Society for Blood and Marrow Transplantation) [47]. Uzyskanie niskiego poziomu MRD mierzonej w szpiku kostnym za pomocą FLC lub metodami molekularnymi 12 miesięcy po allo-HSCT wiązało się $z$ dłuższym czasem wolnym od wznowy (EFS, event-free survival) [25, 48-50]. Ponadto pomiar MRD może mieć zastosowanie $\mathrm{w}$ postępowaniu preemptywnym. W badaniu CLL3X u 3 z 6 pacjentów, u których stwierdzono obecność MRD w szpiku kostnym po allo-HSCT, infuzja limfocytów dawców (DLI, donor lymphocyte infusion) pozwoliła na pogłębienie odpowiedzi, prowadząc do uzyskania CR z negatywizacją MRD [49].

Ocena MRD zdaje się nie mieć znaczenia w ocenie odpowiedzi na leczenie BCRi, jednakże 
obserwacje kliniczne są zbyt krótkotrwałe by móc to ocenić, a brak regularnego oznaczania MRD w przypadku uzyskania CR lub remisji częściowej (PR, partial remission) nie pozwala obecnie wyciagnąć jednoznacznych wniosków. Zarówno w przypadku leczenia ibrutynibem, jak i idelalizybem w skojarzeniu $z$ rytuksymabem odsetek uzyskanych $C R$ jest niski, jednak w nielicznych przypadkach chorych leczonych ibrutynibem stwierdzono negatywizację MRD w krwi obwodowej u około 8\% analizowanych pacjentów [17, 18, 51-53]. W przypadku leczenia skojarzonego BCRi $z$ immunochemioterapią lub innymi nowymi cząsteczkami odsetek ten powinien być wyższy [54].

Zgoła odmienna sytuacja ma miejsce w przypadku leczenia wenetoklaksem - zarówno w monoterapii, jak i w leczeniu skojarzonym $z$ rytuksymabem czy obinutuzumabem [19, 55-58]. W badaniu I fazy w grupie 116 pacjentów z r/r CLL/SLL monoterapia wenetoklaksem charakteryzowała się 79-procentowym ORR z CR/CRi wynoszącym 20\%. U 6 spośród 17 chorych z CR/CRi uzyskano negatywizację MRD w szpiku kostnym (5\% całej badanej grupy pacjentów) [19]. Z kolei w grupie 107 pacjentów $z$ r/r CLL $z$ defektem szlaku białka p53 w wyniku monoterapii wenetoklaksem uzyskano $79 \%$ ORR z 7,5\% CR/CRi. Ponadto u 18 spośród $45(17 \%)$ analizowanych chorych nie wykryto MRD we krwi obwodowej, natomiast u 6 spośród 10 badanych chorych wykazano ujemny wynik badania MRD również w szpiku kostnym [57]. Skojarzenie wenetoklaksu $z$ rytuksymabem prowadzi do pogłębienia odpowiedzi u chorych na r/r CLL/SLL. W grupie 49 chorych leczenie skojarzone doprowadziło do uzyskania $86 \%$ ORR $z$ odsetkiem CR/CRi sięgającym $51 \%$ [56]. Ponadto u 28 z 42 analizowanych pacjentów oraz u 20 chorych, którzy uzyskali CR, osiągnięto negatywizację MRD w szpiku kostnym. W badaniu tym ze względu na krótki okres obserwacji nie osiągnięto mediany PFS ani OS. W ramach badania leczenie wstrzymano u 13 pacjentów, którzy osiągnęli głęboką odpowiedź w wyniku terapii (stwierdzenie CR, CRi lub PR z ujemną MRD). U 2 chorych, u których stwierdzono obecność MRD w szpiku kostnym, obserwowano cechy bezobjawowej progresji CLL (narastanie MRD we krwi obwodowej oraz wzrost limfocytozy). Ponowne włączenie wenetoklaksu skutkowało uzyskanie PR. Wyniki wskazują, że uzyskanie negatywizacji MRD umożliwia przerwanie leczenia wenetoklaksem, a w przypadku nawrotu choroby ponowne włączenie inhibitora BCL2 pozwala na jej ponowną kontrolę [56]. Pogłębienie odpowiedzi obserwowano również w przypadku leczenia skojarzonego wenetoklaksem z obinutuzumabem. W grupie 13 dotychczas nieleczonych chorych na CLL połączenie obu leków prowadziło do uzyskania odpowiedzi u wszystkich pacjentów, przy czym negatywizację MRD we krwi obwodowej uzyskano u 11 z 12 pacjentów. W 5 spośród 7 przypadków, analizując poziom MRD w szpiku kostnym, stwierdzono jego negatywizację [59].

Uzyskanie eradykacji MRD zdaje się dokładniejszym parametrem prognostycznym niż samo uzyskanie CR lub PR w wyniku zastosowania immunochemioterapii, o czym świadczą wyniki obserwacyjnego badania Kovacs i wsp. [23] przeprowadzonego w grupie 554 chorych leczonych $\mathrm{w}$ randomizowanych badaniach CLL8 (FCR $v$. FC) oraz CLL10 (FCR $v$. BR). Przypadki CR-MRD(-), PR-MRD(-), CR-MRD(+) oraz PR-MRD(+) charakteryzowały się odpowiednio zróżnicowanymi czasami PFS wynoszącymi odpowiednio 61 miesięcy, 54 miesięcy, 35 miesięcy oraz 21 miesięcy. Wykazano również, że przypadki PR-MRD(-) $z$ towarzyszącą splenomegalią cechowało porównywalne PFS (63 mies.), natomiast przypadki PR-MRD(-) z towarzyszącą limfadenopatią — istotnie krótsze (32 mies.) w odniesieniu do przypadków CR-MRD(-) (61 mies.) [23]. Wytłumaczeniem takiej zależności może być oporność białaczkowych komórek znajdujących się w węzłach chłonnych. Brakuje jednak obecnie badań, w których oceniono by chorobę resztkową CLL na podstawie analizy molekularnej czy cytometrycznej węzłów chłonnych.

\section{Miejsce oceny MRD w świetle wytycznych międzynarodowych oraz krajowych}

Ocena MRD jest metodą uznaną w charakteryzacji głębokości odpowiedzi na leczenie (wytyczne NCCN [National Comprehensive Cancer Network] oraz iwCLL), jednak $z$ powodu braku wyników badań prospektywnych nie zaleca się jej w rutynowej praktyce klinicznej [27,60]. Oznaczenie MRD jest natomiast zalecane w przypadku oceny odpowiedzi na leczenie w ramach badań klinicznych [27]. Brakuje, jak dotychczas, ostatecznego konsensusu dotyczącego optymalnego momentu oznaczania MRD ( $z$ reguły oznaczenie wykonywano w okresie 2-3 miesięcy po zakończenia immunochemioterapii) oraz rodzaju pobieranego materiału klinicznego (krew obwodowa $v$. szpik kostny $v$. rezydualne masy węzłowe). Jakkolwiek oznaczenie MRD we krwi obwodowej 2-3 miesięcy po leczeniu jest w większości przypadków bardzo dobrym surogatem PFS, to badanie aspiratu szpiku 
kostnego wydaje się bardziej czułe i wiarygodne. Odsetek pacjentów z negatywną MRD we krwi obwodowej i pozytywną w szpiku może sięgać $20 \%$ [61]. Obecnie przyjmuje się, że badanie MRD $\mathrm{w}$ aspiracie szpiku, jako bardziej inwazyjne, należy wykonać w przypadku negatywnego wyniku MRD we krwi obwodowej. Dowiedziono zasadności oznaczania MRD w przypadku stosowania immunochemioterapii, co jest związane $z$ długoletnimi obserwacjami, jednak otwartą kwestią pozostaje wykorzystanie jej do oceny odpowiedzi na leczenie BCRi oraz wenetoklaksem ze względu na brak jej rutynowego oznaczania $\mathrm{w}$ dotychczas przeprowadzonych badaniach klinicznych w przypadku uzyskiwanych odpowiedzi oraz krótkich czasów obserwacji. Obecnie są realizowane badania służące określeniu roli oznaczania MRD w ocenie odpowiedzi na coraz bardziej zróżnicowane schematy leczenia CLL, jak również wykorzystujące negatywizację MRD do zakończenia lub zmiany postępowania terapeutycznego. Europejska Agencja Leków rozważa zastosowanie badania MRD w CLL jako pośredniego punktu końcowego dla rejestracji wybranych terapii w randomizowanych badaniach klinicznych zaprojektowanych w celu wykazania przewagi w zakresie PFS.

W Polsce aktualnie brakuje wytycznych dotyczących oznaczania MRD w CLL. Biorąc pod uwagę realia krajowe, głównie koszty oraz dostępność aparaturową i doświadczenie personelu ośrodków, oznaczanie MRD z zastosowaniem FLC będzie główną metodą wykorzystywaną w tym celu.

\section{Podsumowanie}

Weryfikacja oznaczania MRD w kontekście uzyskiwanych odpowiedzi w zakresie czasów PFS i OS oraz uzależnienia dalszego postępowania terapeutycznego $\mathrm{w}$ badaniach prospektywnych pozwoli na ugruntowanie tej metody w wytycznych krajowych i międzynarodowych dotyczących CLL. Niemniej, biorąc pod uwagę dużą heterogenność CLL oraz mnogość dostępnych obecnie schematów terapeutycznych, walidacja MRD może się okazać utrudniona i, być może, będzie stosowana wyłącznie jako marker odpowiedzi jedynie w przypadku wybranych schematów terapeutycznych.

\section{Podziękowania}

Praca powstała w ramach działalności Klubu Młodego Hematologa.

\section{Piśmiennictwo}

1. Swerdlow S, Campo E, Harris N. WHO Classification of Tumours of Haematopoietic and Lymphoid Tissues. IARC 2017.

2. Kipps TJ, Stevenson FK, Wu CJ, et al. Chronic lymphocytic leukaemia. Nat Rev Dis Primers. 2017; 3: 16096, doi: 10.1038/ nrdp.2016.96, indexed in Pubmed: 28102226.

3. Matutes E, Owusu-Ankomah K, Morilla R, et al. The immunological profile of B-cell disorders and proposal of a scoring system for the diagnosis of CLL. Leukemia. 1994; 8(10): 1640-1645, indexed in Pubmed: 7523797.

4. Dighiero G, Hamblin TJ. Chronic lymphocytic leukaemia. The Lancet. 2008; 371(9617): 1017-1029, doi: 10.1016/s01406736(08)60456-0.

5. Białopiorowicz E, Juszczyński P. Molekularna patogeneza przewlekłej białaczki limfocytowej. Hematologia. 2017; 7(4): 273-286, doi: 10.5603/hem.2016.0026.

6. Landau DA, Carter SL, Stojanov P, et al. Evolution and impact of subclonal mutations in chronic lymphocytic leukemia. Cell. 2013; 152(4): 714-726, doi: 10.1016/j.cell.2013.01.019, indexed in Pubmed: 23415222.

7. Landau DA, Tausch E, Taylor-Weiner AN, et al. Mutations driving CLL and their evolution in progression and relapse. Nature. 2015; 526(7574): 525-530, doi: 10.1038/nature15395, indexed in Pubmed: 26466571.

8. Döhner H, Stilgenbauer S, Benner A, et al. Genomic aberrations and survival in chronic lymphocytic leukemia. N Engl J Med. 2000; 343(26): 1910-1916, doi: 10.1056/NEJM200012283432602, indexed in Pubmed: 11136261.

9. Eichhorst B, Robak T, Montserrat E, et al. ESMO Guidelines Committee. Chronic lymphocytic leukaemia: ESMO Clinical Practice Guidelines for diagnosis, treatment and follow-up. Ann Oncol. 2015; 26(Suppl 5): v78-v84, doi: 10.1093/annonc/mdv303, indexed in Pubmed: 26314781.

10. Robak T, Hus I, Giannopoulos K, et al. Rekomendacje diagnostyczne i terapeutyczne dla przewlekłej białaczki limfocytowej w 2016 r - Raport Grupy Roboczej PTHiT i PALG-CLL. Acta Haemat Pol. 2016; 47(3): 169-183, doi: 10.1016/j.achaem.2016.08.003.

11. Hallek M, Fischer K, Fingerle-Rowson G, et al. International Group of Investigators, German Chronic Lymphocytic Leukaemia Study Group. Addition of rituximab to fludarabine and cyclophosphamide in patients with chronic lymphocytic leukaemia: a randomised, open-label, phase 3 trial. Lancet. 2010; 376(9747): 1164-1174, doi: 10.1016/S0140-6736(10)61381-5, indexed in Pubmed: 20888994.

12. Barrientos JC. Management of chronic lymphocytic leukemia in the elderly. Cancer Control. 2015; 22(4 Suppl): 17-23, doi: 10.1177/107327481502204s04, indexed in Pubmed: 26618342.

13. Hillmen P, Robak T, Janssens A, et al. COMPLEMENT 1 Study Investigators. Chlorambucil plus ofatumumab versus chlorambucil alone in previously untreated patients with chronic lymphocytic leukaemia (COMPLEMENT 1): a randomised, multicentre, open-label phase 3 trial. Lancet. 2015; 385(9980): 1873-1883, doi: 10.1016/S0140-6736(15)60027-7, indexed in Pubmed: 25882396.

14. Goede V, Fischer K, Busch R, et al. Obinutuzumab plus chlorambucil in patients with CLL and coexisting conditions. N Engl J Med. 2014; 370(12): 1101-1110, doi: 10.1056/NEJMoa1313984, indexed in Pubmed: 24401022. 
15. Goede V, Fischer K, Engelke A, et al. Obinutuzumab as frontline treatment of chronic lymphocytic leukemia: updated results of the CLL11 study. Leukemia. 2015; 29(7): 1602-1604, doi: 10.1038/ leu.2015.14, indexed in Pubmed: 25634683.

16. Burger JA, Tedeschi A, Barr PM, et al. RESONATE-2 Investigators. Ibrutinib as initial therapy for patients with chronic lymphocytic leukemia. N Engl J Med. 2015; 373(25): 2425-2437, doi: 10.1056/NEJMoa1509388, indexed in Pubmed: 26639149.

17. Byrd JC, Brown JR, O’Brien S, et al. RESONATE Investigators. Ibrutinib versus ofatumumab in previously treated chronic lymphoid leukemia. N Engl J Med. 2014; 371(3): 213-223, doi: 10.1056/NEJMoa1400376, indexed in Pubmed: 24881631.

18. Furman RR, Sharman JP, Coutre SE. Idelalisib and rituximab in relapsed chronic lymphocytic leukemia. N Engl J Med. I2014; 370(11): 997-1007, doi: 10.1056/NEJMoa1315226.

19. Roberts AW, Davids MS, Pagel JM, et al. Targeting BCL2 with venetoclax in relapsed chronic lymphocytic leukemia. N Engl J Med. 2016; 374(4): 311-322, doi: 10.1056/NEJMoa1513257, indexed in Pubmed: 26639348.

20. Rossi D, Cerri M, Deambrogi C, et al. The prognostic value of TP53 mutations in chronic lymphocytic leukemia is independent of Del17p13: implications for overall survival and chemorefractoriness. Clin Cancer Res. 2009; 15(3): 995-1004, doi: 10.1158/1078-0432.CCR-08-1630, indexed in Pubmed: 19188171.

21. Jamroziak K, Puła B, Walewski J. Current treatment of chronic lymphocytic leukemia. Curr Treat Options Oncol. 2017; 18(1): 5, doi: 10.1007/s11864-017-0448-2, indexed in Pubmed: 28185174.

22. Fischer K, Bahlo J, Fink AM, et al. Long-term remissions after FCR chemoimmunotherapy in previously untreated patients with CLL: updated results of the CLL8 trial. Blood. 2016; 127(2): 208-215, doi: 10.1182/blood-2015-06-651125, indexed in Pubmed: 26486789 .

23. Kovacs G, Robrecht S, Fink AM, et al. Minimal residual disease assessment improves prediction of outcome in patients with chronic lymphocytic leukemia (CLL) who achieve partial response: comprehensive analysis of two phase III studies of the German CLL Study Group. J Clin Oncol. 2016; 34(31): 3758-3765, doi: 10.1200/JCO.2016.67.1305, indexed in Pubmed: 27573660.

24. Rawstron AC, Fazi C, Agathangelidis A, et al. A complementary role of multiparameter flow cytometry and high-throughput sequencing for minimal residual disease detection in chronic lymphocytic leukemia: an European Research Initiative on CLL study. Leukemia. 2016; 30(4): 929-936, doi: 10.1038/leu.2015.313, indexed in Pubmed: 26639181.

25. Logan AC, Zhang B, Narasimhan B, et al. Minimal residual disease quantification using consensus primers and high-throughput IGH sequencing predicts post-transplant relapse in chronic lymphocytic leukemia. Leukemia. 2013; 27(8): 1659-1665, doi: 10.1038/leu.2013.52, indexed in Pubmed: 23419792.

26. Faham M, Zheng J, Moorhead M, et al. Deep-sequencing approach for minimal residual disease detection in acute lymphoblastic leukemia. Blood. 2012; 120(26): 5173-5180, doi: 10.1182/ blood-2012-07-444042, indexed in Pubmed: 23074282.

27. Hallek M, Cheson BD, Catovsky D, et al. Guidelines for diagnosis, indications for treatment, response assessment and supportive management of chronic lymphocytic leukemia. Blood. 2018 [ahead of print].

28. Eichhorst B, Fink AM, Bahlo J, et al. international group of investigators, German CLL Study Group (GCLLSG). First-line chemoimmunotherapy with bendamustine and rituximab versus fludarabine, cyclophosphamide, and rituximab in patients with advanced chronic lymphocytic leukaemia (CLL10): an international, open-label, randomised, phase 3, non-inferiority trial. Lancet Oncol. 2016; 17(7): 928-942, doi: 10.1016/S1470-2045(16)300511, indexed in Pubmed: 27216274.

29. Rawstron AC, Villamor N, Ritgen M, et al. International standardized approach for flow cytometric residual disease monitoring in chronic lymphocytic leukaemia. Leukemia. 2007; 21(5): 956-964, doi: 10.1038/sj.leu.2404584, indexed in Pubmed: 17361231.

30. Rawstron AC, Böttcher S, Letestu R, et al. European Research Initiative in CLL. Improving efficiency and sensitivity: European Research Initiative in CLL (ERIC) update on the international harmonised approach for flow cytometric residual disease monitoring in CLL. Leukemia. 2013; 27(1): 142-149, doi: 10.1038/ leu.2012.216, indexed in Pubmed: 23041722.

31. Stehlíková O, Chovancová J, Tichý B, et al. Detecting minimal residual disease in patients with chronic lymphocytic leukemia using 8-color flow cytometry protocol in routine hematological practice. Int J Lab Hematol. 2014; 36(2): 165-171, doi: 10.1111/ ijlh.12149, indexed in Pubmed: 24028768.

32. Dowling AK, Liptrot SD, O'Brien D, et al. Optimization and validation of an 8-color single-tube assay for the sensitive detection of minimal residual disease in B-cell chronic lymphocytic leukemia detected via flow cytometry. Lab Med. 2016; 47(2): 103-111, doi: 10.1093/labmed/lmw006, indexed in Pubmed: 27069028.

33. Sartor MM, Gottlieb DJ. A single tube 10-color flow cytometry assay optimizes detection of minimal residual disease in chronic lymphocytic leukemia. Cytometry B Clin Cytom. 2013; 84(2): 96-103, doi: 10.1002/cyto.b.21067, indexed in Pubmed: 23283845.

34. Böttcher S, Hallek M, Ritgen M, et al. The role of minimal residual disease measurements in the therapy for CLL: is it ready for prime time? Hematol Oncol Clin North Am. 2013; 27(2): 267-288, doi: 10.1016/j.hoc.2013.01.005, indexed in Pubmed: 23561473.

35. Pfitzner T, Engert A, Wittor H, et al. A real-time PCR assay for the quantification of residual malignant cells in B cell chronic lymphatic leukemia. Leukemia. 2000; 14(4): 754-766, indexed in Pubmed: 10764166.

36. van der Velden VHJ, Hochhaus A, Cazzaniga G, et al. Detection of minimal residual disease in hematologic malignancies by real-time quantitative PCR: principles, approaches, and laboratory aspects. Leukemia. 2003; 17(6): 1013-1034, doi: 10.1038/ sj.leu.2402922, indexed in Pubmed: 12764363.

37. Ladetto M, Brüggemann M, Monitillo L, et al. Next-generation sequencing and real-time quantitative PCR for minimal residual disease detection in B-cell disorders. Leukemia. 2014; 28(6): 1299-1307, doi: 10.1038/leu.2013.375, indexed in Pubmed: 24342950.

38. Thompson PA, Wierda WG. Eliminating minimal residual disease as a therapeutic end point: working toward cure for patients with CLL. Blood. 2016; 127(3): 279-286, doi: 10.1182/ blood-2015-08-634816, indexed in Pubmed: 26576865.

39. Böttcher S, Ritgen M, Fischer K, et al. Minimal residual disease quantification is an independent predictor of progression-free and overall survival in chronic lymphocytic leukemia: a multivariate analysis from the randomized GCLLSG CLL8 trial. J Clin Oncol. 2012; 30(9): 980-988, doi: 10.1200/JCO.2011.36.9348, indexed in Pubmed: 22331940.

40. Strati P, Keating MJ, O'Brien SM, et al. Eradication of bone marrow minimal residual disease may prompt early treatment discontinuation in CLL. Blood. 2014; 123(24): 3727-3732, doi: 10.1182/blood-2013-11-538116, indexed in Pubmed: 24705492. 
41. Mössner E, Brünker P, Moser S, et al. Increasing the efficacy of CD20 antibody therapy through the engineering of a new type II anti-CD20 antibody with enhanced direct and immune effector cell-mediated B-cell cytotoxicity. Blood. 2010; 115(22): 4393-4402, doi: 10.1182/blood-2009-06-225979, indexed in Pubmed: 20194898 .

42. Fischer $\mathrm{K}$, Cramer $\mathrm{P}$, Busch R, et al. Bendamustine in combination with rituximab for previously untreated patients with chronic lymphocytic leukemia: a multicenter phase II trial of the German Chronic Lymphocytic Leukemia Study Group. J Clin Oncol. 2012; 30(26): 3209-3216, doi: 10.1200/JCO.2011.39.2688, indexed in Pubmed: 22869884.

43. Bosch F, Ferrer A, Villamor N, et al. Fludarabine, cyclophosphamide, and mitoxantrone as initial therapy of chronic lymphocytic leukemia: high response rate and disease eradication. Clin Cancer Res. 2008; 14(1): 155-161, doi: 10.1158/1078-0432.CCR-07-1371, indexed in Pubmed: 18172266.

44. Wierda W, O'Brien S, Wen S, et al. Chemoimmunotherapy with fludarabine, cyclophosphamide, and rituximab for relapsed and refractory chronic lymphocytic leukemia. J Clin Oncol. 2005; 23(18): 4070-4078, doi: 10.1200/JCO.2005.12.516, indexed in Pubmed: 15767647.

45. Moreton P, Kennedy B, Lucas G, et al. Eradication of minimal residual disease in B-cell chronic lymphocytic leukemia after alemtuzumab therapy is associated with prolonged survival. J Clin Oncol. 2005; 23(13): 2971-2979, doi: 10.1200/JCO.2005.04.021, indexed in Pubmed: 15738539.

46. Pettitt AR, Jackson R, Carruthers S, et al. Alemtuzumab in combination with methylprednisolone is a highly effective induction regimen for patients with chronic lymphocytic leukemia and deletion of TP53: final results of the national cancer research institute CLL206 trial. J Clin Oncol. 2012; 30(14): 1647-1655, doi: 10.1200/ JCO.2011.35.9695, indexed in Pubmed: 22493413.

47. Kharfan-Dabaja MA, Kumar A, Hamadani M, et al. Clinical practice recommendations for use of allogeneic hematopoietic cell transplantation in chronic lymphocytic leukemia on behalf of the guidelines Committee of the American Society for Blood and Marrow Transplantation. Biol Blood Marrow Transplant. 2016; 22(12): 2117-2125, doi: 10.1016/j.bbmt.2016.09.013, indexed in Pubmed: 27660167.

48. Moreno C, Villamor N, Colomer D, et al. Clinical significance of minimal residual disease, as assessed by different techniques, after stem cell transplantation for chronic lymphocytic leukemia. Blood. 2006; 107(11): 4563-4569, doi: 10.1182/ blood-2005-09-3634, indexed in Pubmed: 16449533.

49. Dreger P, Döhner H, Ritgen M, et al. German CLL Study Group. Allogeneic stem cell transplantation provides durable disease control in poor-risk chronic lymphocytic leukemia: long-term clinical and MRD results of the German CLL Study Group CLL3X trial. Blood. 2010; 116(14): 2438-2447, doi: 10.1182/ blood-2010-03-275420, indexed in Pubmed: 20595516.
50. Farina L, Carniti C, Dodero A, et al. Qualitative and quantitative polymerase chain reaction monitoring of minimal residual disease in relapsed chronic lymphocytic leukemia: early assessment can predict long-term outcome after reduced intensity allogeneic transplantation. Haematologica. 2009; 94(5): 654-662, doi: 10.3324/haematol.2008.000273, indexed in Pubmed: 19377072.

51. Puła B, Iskierka-Jażdżewska E, Hus M, et al. Analiza skuteczności ibrutynibu w podgrupie chorych na przewlekłą białaczkę limfocytową z delecją 17p: badanie obserwacyjne Polskiej Grupy ds. Leczenia Białaczek u Dorosłych (PALG). Acta Haematol Pol. 2017; 48(4): 330-337, doi: 10.1016/j.achaem.2017.10.004.

52. Iskierka-Jażdżewska E, Hus M, Giannopoulos K, et al. Efficacy and toxicity of compassionate ibrutinib use in relapsed/refractory chronic lymphocytic leukemia in Poland: analysis of the Polish Adult Leukemia Group (PALG). Leuk Lymphoma. 2017; 58(10): 2485-2488, doi: 10.1080/10428194.2017.1292353, indexed in Pubmed: 28278701.

53. Ahn IE, Farooqui MZH, Tian X, et al. Depth and durability of response to ibrutinib in CLL: 5-year follow-up of a phase 2 study. Blood. 2018; 131(21): 2357-2366, doi: 10.1182/ blood-2017-12-820910, indexed in Pubmed: 29483101.

54. Thompson M, Brander D, Nabhan C, et al. Minimal residual disease in chronic lymphocytic leukemia in the era of novel agents: a review. JAMA Oncol. 2018; 4(3): 394-400, doi: 10.1001/jamaoncol.2017.2009, indexed in Pubmed: 28750119.

55. Flinn IV, Brunvand M, Choi M.Y. MY. Safety and efficacy of a combination of venetoclax (GDC-0199/ABT-199) and obinutuzumab in patients with relapsed/refractory or previously untreated chronic lymphocytic leukemia - results from a phase $1 \mathrm{~b}$ study (GP28331). Blood. 2015; 126(23): 494.

56. Seymour JF, Ma S, Brander DM, et al. Venetoclax plus rituximab in relapsed or refractory chronic lymphocytic leukaemia: a phase 1b study. Lancet Oncol. 2017; 18(2): 230-240, doi: 10.1016/S14702045(17)30012-8, indexed in Pubmed: 28089635.

57. Stilgenbauer S, Eichhorst B, Schetelig J, et al. Venetoclax in relapsed or refractory chronic lymphocytic leukaemia with $17 \mathrm{p}$ deletion: a multicentre, open-label, phase 2 study. Lancet Oncol. 2016; 17(6): 768-778, doi: 10.1016/S1470-2045(16)30019-5, indexed in Pubmed: 27178240.

58. Puła B, Jamroziak K. Rola wenetoklaksu w leczeniu chorych na przewlekłą białaczkę limfocytową. Hematologia. 2017; 8(1): 20-32, doi: 10.5603/hem.2017.0003.

59. Fischer K, Al-Sawaf O, Fink AM. Venetoclax and obinutuzumab in chronic lymphocytic leukemia. Blood 2017. 2017; 129(19): 2705.

60. NCCN Clinical Practice Guidelines in Oncology (NCCN Guidelines). Chronic Lymphocytic Leukemia/Small Lymphocytic Lymphoma. Version I. 31 March 2017.

61. Rawstron AC, Howard D, McParland L, et al. Compartment Effect on the Prognostic Significance of MRD Detection in CLL: Impact of Treatment Type and Duration of Follow-up. Blood. 2016; 128(22): 3226-3226. 